\title{
Resilience in Sensemaking and Control of Emergency Response
}

\author{
Jonas Lundberg, Eva Törnqvist and Simin Nadjm-Tehrani
}

\section{Linköping University Post Print}

N.B.: When citing this work, cite the original article.

Original Publication:

Jonas Lundberg, Eva Törnqvist and Simin Nadjm-Tehrani, Resilience in Sensemaking and Control of Emergency Response, 2012, International Journal of Emergency Management, (8), 2, 99-122.

http://dx.doi.org/10.1504/IJEM.2012.046009

Copyright: Inderscience

http://www.inderscience.com/

Postprint available at: Linköping University Electronic Press

http://urn.kb.se/resolve?urn=urn:nbn:se:liu:diva-78855 


\title{
Resilience in Sensemaking and Control
}

\section{of Emergency Response}

\author{
Corresponding author: Jonas Lundberg \\ Linköping University, Department of Science and Technology, \\ Campus Norrköping, 60174 Norrköping, Sweden \\ Jonas.lundberg@liu.se \\ Phone: +46 (0) 11363452 \\ Fax: +46(0) 11363270 \\ Eva Törnqvist \\ Technology \& Social Change at the Tema Institute, \\ Linköping University, Sweden \\ eva.tornqvist@liu.se \\ Simin Nadjm-Tehrani \\ Dept. of Computer \& Information Science \\ Linköping University, Sweden \\ simin.nadjm-tehrani@liu.se
}

Abstract: This paper proposes a model for describing resilience in emergency management of irregular events. The purpose of our model is to describe three parallel developments in an emergency response scenario. Namely, changes in the ongoing events processes, the actors' sensemaking and control functions, and the technologies used for sensemaking and control. Focusing on the three separate developments enables identifying resilience in the choice of control functions and technologies in response to foreseen and actual process changes, their consequences and new disturbances. Our model was created following an emergency exercise that proved to be difficult to analyze with respect to resilience using existing models. We use the exercise to illustrate and apply our model through a qualitative analysis.

Keywords: resilience; sensemaking; sense making; emergency management; situation awareness; boundary spanning; cross scale interactions; buffering capacity; information technology; resource management; distributed cognition; cognitive control model; requisite variety; emergency response 


\section{Biographical notes}

Jonas Lundberg, Ph. D, is a researcher and lecturer at the Department of Science and Technology, Linköping University. He is currently working in projects about resilience in emergency response and resilience in accident investigation. He has a $\mathrm{PhD}$ in Computer Science, in the area of Human-Computer Interaction. His research interest is in the design of complex systems, in particular resilience engineering, cognitive systems engineering, interaction design and information design.

Eva Törnqvist, Ph. D. is researcher and lecturer at The Department of Technology and Social Change at Linköping University, Sweden. She is also Director for The Centre for Man, Technology and Society at Linköping University. Her research is within the field of communication, learning and ICT. Her research projects are about how knowledge produced in one environment is transferred and made available and applicable in another with partial different conditions, how changed technological possibilities influences communicative conditions and how everyday users of energy demanding ICT in an innovative way incorporates them in their practices.

Simin Nadjm-Tehrani is a full professor at Linköping university, Sweden. She has led the realtime systems laboratory (RTSLAB) at the department of Computer and Information Science since year 2000. She obtained her BSc from Manchester University, England, and her PhD from Linköping University in 1994. In 2006-2008 she worked as a full professor at University of Luxembourg. Her current research interest is in the area of dependable distributed systems and networks, including analysis of safety and fault tolerance, reliable communication and ensuring availability in presence of failures, attacks and overloads.

\section{Introduction}

Most emergency situations in Sweden are not disasters, since there are no major earthquakes, no extreme fires, and no extreme flooding in Sweden - at least there have not been in the last hundred years. Emergencies that irregularly occur are of a more minor and local kind; for instance, the flooding of a city, loss of electricity over a large part of the countryside or a big city, a sizeable but not enormous fire. The challenge for the rescue effort is thus different from a larger disaster. It needs to focus on restoring services by alternative means, on temporary measures to avoid threats to life, and on rescuing people who are in peril by for instance being stuck in a car 
in a cold winter on a countryside road. Nevertheless, there are similarities with larger disasters. In particular, there is a need for resilience, that is, adaptation to the changes in the situation, for instance an unusually high demand for limited resources, often together with breakdown of communications technology and other technical systems. It is not uncommon to conduct exercises in order to be prepared for irregular emergency events. However, when it comes to learning from the analysis of the performed exercise, we found that the existing models in the literature do not explicitly address the problem of identifying and describing resilience building processes.

Our goal is to study resilience related to sensemaking and control in emergency management of irregular emergencies. We conducted a case study of an emergency exercise, which took place in a small municipality in the countryside of Sweden during one evening and one working day. The focus of the exercise was an escalating event. The scenario was a storm causing an electricity outage affecting both citizens and the rescue operation, slowly spreading, and then dramatically expanding by an accident during the restoration effort.

In this study we analyze processes and factors that underlie resilient action or lack thereof in the exercise. We first attempted the analysis based on existing models. This illustrated a lack of support for delineation of resilience factors in the existing models. We found that the models could be more explicit regarding adaptation of variety of actors' responses and technology variety (i.e. capabilities to deal with disturbances) in response to changes in the situation. This led to a refined model based on a grounded analysis approach.

In the next section we provide an overview of three existing models from three different research communities, two of which normally do not refer to each other. Our emergency management analysis model, the resilient sensemaking and variety control model (RESCOM), will be described in section 4 of the paper. This model unifies and complements the existing models by explicitly 
modelling resilience factors and the actors' sensemaking and control functions and technologies' variety. Section 3 describes the methods used to collect data on the case study. Section 5 describes the case study in relation to the different models, i.e. illustrating RESCOM elements and showing that the existing models have difficulties in describing resilience. We draw some conclusions in section 6.

\section{Overview of existing models}

In emergencies the work aims at countering disturbances to normal situations, to bounce back or to absorb events. This mechanism is often conceptualized as resilience, i.e. successful adaption to disturbances by a system is seen as resilient behaviour. Manynena (2006) reviews definitions of resilience, and ends up defining disaster resilience as intrinsic adaptive capacity. Woods (2006) narrows down resilience from adaptive capacity in general, to adaptive capacity of the response system to meet challenges that go outside of the normal adaptive strategies of the system. Regardless of whether the adaption follows conventional strategies or demands shifts in the ways of working, adaptation is an important characteristic in emergency situations (see e.g. Comfort, 1996).

Resilience can be broken down into factors of resilient action, e.g. buffering capacity (capacity to deal with different disturbances), tolerance (effects of uncontrolled disturbances), margin (how close the system is to lose control), flexibility (ability to alter strategy or modify objects), crossscale interactions (interactions between parts and whole of the organisation), boundary spanning (help regarding sensemaking or control is given or received to/from other organizations, rather than through an adjustment of the own organization) (Mendonca and Wallace, 2006; Woods, 2006). From a sensemaking perspective, resilience can be seen as improvisation / bricolage (the 
ability to understand how available resources can be useful to cope with a novel situation, and make do with it to adapt), virtual role systems (the ability to 'think' other people's roles, to compensate for them being missing), wisdom (combination of some doubt and previous experience), respectful interaction (reporting honestly, trusting others reports, sharing and integrating) (Weick, 1993), robustness (the amount of stress that can be absorbed before degradation), redundancy (substitutable units), rapidity (response in a timely manner) (Kendra and Wachtendorf, 2003)

Turning to adaptive behaviour, needed for emergency response, it is instructive to look more closely at what needs to be adapted to gain or maintain control of a situation. As Ashby describes, control requires variety, which consists of the possible responses of a regulator to a variety of disturbances. The law of requisite variety states that the only way of countering more variety of disturbances is by more variety in the controller (1956). The importance of variety for sensemaking has been emphasized by Weick (1995, 2001, Weick \& Suthclife 2007). When variety is lacking, people may miss information and make short-sighted remedies (Weick, 2001).

Ashby models control in an input-output table. In the first column, there are the possible events or disturbances of the world that selects a row of possible outcomes. In the top row, there are the possible responses of the regulator, that when selected, specifies a column of responses. At the intersection between disturbance and response lies the outcome. In a perfect regulator, the outcome is always the indented one, regardless of the disturbance. More variety in the regulator means more items in the top row (more columns in the table), whereas more variety in the disturbance means more items in the first column (more rows in the table). Depicted as such a table, it is easy to see that only more variety in the controller can match more variety in the environment. 
However, it is equally evident that no emergency manager can expect to have infinite variety, that is, to have an infinite number of responses to every imaginable and unimaginable disturbance. As Weick (2001) notes, variety can be managed by simplifying the problem situation (reducing its variety), or by increasing sensemaking variety. Therefore, emergency management must adapt its ability to respond to the disturbances at hand, in effect changing its variety rather than merely increasing it. Rather than merely selecting a response, from a ready-made table, it must adapt and create a suitable response; either by following ready-made plans for adaptation, or by making sense of the situation and to create responses during the unfolding event.

To act in an emergency situation, an understanding of the situation, and the process of achieving the understanding are thus central, which has previously been conceptualized as situation awareness and sensemaking. As Weick (1995) described, sensemaking is what people do in order to decide how to act in the situations they encounter. Sensemaking is thus closely related to situation awareness, which can be seen as a product of sensemaking. Endsley (1988) defined situation awareness as both the awareness of the current situation and the situation in the future.

Control, sensemaking, and situation awareness are often brought together in models that resemble the perceptual cycle (Neisser, 1976), and are in some cases explicitly built on it (Hollnagel, 2000; Smith and Hancock, 1995). The perceptual cycle (figure 1.) by Neisser (1976) has been used to describe the relation between the process of sensemaking, and the product of situation awareness (Lundberg, 2002; Smith and Hancock, 1995; Tenney et al., 1992). In figure 1 the perceptual cycle is shown, with a "schema" to the left. The schema represents plans for perceptual action and readiness for particular information structures. It directs perceptual action that samples the available information, which in turn modifies the schema. Neisser differentiates schema that are about something specific from orienting schema, that are also called cognitive 
maps, that contain other schema and relate them to each other (Neisser, 1976). Situation awareness can either refer to the actors' current schema (Lundberg, 2002), or to the adaptation of the agent in terms of being prepared to direct perceptual exploration of cues in the environment that are relevant to the goals, criteria, and constraints of the dynamic tasks in the environment (Smith and Hancock, 1995).

Similarly, Brehmer (2007) has proposed that sensemaking in the military domain can be described as in figure 2 by the dynamic observe, orient, decide, and act loop (DOODA). We have included a military command and control (C2) model in this paper, since there can be similarities between military $\mathrm{C} 2$ and emergency management. The focus of the model is on preconditions between functions. The data collection function in DOODA controls sensors (including human observers), and outputs data, as a precondition for the sensemaking function. The output of the sensemaking function is an understanding of what needs to be done, which serves as a precondition for the planning function that outputs orders, a plan of how to achieve what needs to be done. The actual doing is represented by "military activity".

Hollnagel (2000) has explicitly based the contextual control model (COCOM) on the perceptual cycle. As depicted in figure 3, COCOM models quality of control (control mode). It models relations between control mode, control (choice of next action) and construct, competence, subjectively available time, and number of goals. Higher control modes relies more on feedforward, and lower modes more on contextual factors (feedback). COCOM has been complemented by the extended control model (ECOM), that divides control into different time spans (Hollnagel and Woods, 2005). Ecom divides activities into four concurrent processes. The targeting loop sets high level objectives regarding what needs to be done. The monitoring loop keeps track of 
overall progress and makes long-term plans. The regulating loop provides short-term plans, such as manoeuvring around objects. The tracking loop executes the plans.

The models cited here focus on expected and actual outcomes of control actions, as well as on making sense of disturbances and their consequences. This partly corresponds to what we observed during the exercise. We did observe sensemaking and control regarding the ongoing event process, i.e. external events in the physical environment. However, we also observed sensemaking and control with respect to two additional developments. First, we observed how actors made sense of and controlled their own functions, of events and developments in their internal work. Second, we observed events and developments related to technologies, which acted as a bridge between the ongoing events processes and the actors' functions. In previous models these two developments are included as "planning" (figure 2) and "plans" (figure 3). However, what we observed was too complex to be simplified as a planning function, or plans and templates.

\section{Methods}

This research uses a qualitative case study approach. To get as realistic data as possible about actual real-life sensemaking and control during an emergency, a two-day exercise was observed.

Data was collected by observation and recording of audio and video. We recorded audio of the emergency management room during the first day and both video and audio during the second day. One observer was present during the entire second day, in the management room. One observer, who was relieved after lunch, followed the person responsible for communications with the public during the second day. Before lunch, during the most intense period, one additional observer was present in the management room. The management meetings during day two were transcribed at the level of what people were saying and doing, based on the video and audio 
recordings. False starts and hesitations were not included in the transcriptions. Notes taken by the observers during the whole exercise were also included in the analysis, as a basis for reviewing audio and video of episodes outside of the management meetings.

The qualitative data analysis started out with theories of sensemaking, control and resilience, and an abstraction of existing models in the form of a basic control loop. We focused on identifying what the actors were doing to make sense of and control the ongoing events, and what properties of resilience those corresponded to (examples of boundary spanning, buffering capacity, etc). This led to the basic control loop for analysis of resilience (figure 4). Overarching analysis categories also emerged, corresponding to the sensemaking and control domains that were missing in existing models (events process, actors functions, and sensemaking and control technologies). We then refined the basic loop to create the RESCOM model. Finally, a new analysis round was carried out to validate RESCOM (Section 5).

There were of course limitations in the use of the exercise as a means to evaluate a real scenario. Pressure from the public to get in touch with emergency management was limited in the exercise compared to what can be expected in real events. For instance, during an event in the 90's the emergency services got 600 calls about a burning warehouse during a few minutes, and 10000 calls during 3,5 hours (Artman, 1999). Although this is a limitation regarding judgments of performance, it should be noted that no conclusions are made with respect to performance of the effort as a whole.

\section{Resilient sensemaking and variety control model}

In figure 5, our refined model for analysis of resilience in irregular events in emergency management (RESCOM) is presented. It complements the earlier proposed models, integrating prop- 
erties of resilient action proposed by previous research (e.g. Kendra and Wachtendorf, 2003; Mendonca and Wallace, 2006; Weick, 1993; Woods, 2006). Three cyclical sensemaking and control models have been combined to emphasize different sensemaking and control domains, of three parallel developments.

We describe RESCOM in two steps. First, by clarifying the addition of factors of resilience to the basic control loop, and then by clarifying the three control domains.

\subsection{Modeling resilience in a basic control loop}

Each cycle in the RESCOM model (figure 5) corresponds to a basic control loop (figure 4) that extends the perceptual cycle (figure 1) with factors of control and resilience.

Each circle includes feedforward control based on anticipation of outcomes of the situation, as well as feedback control based on observed outcomes. The actor's understanding (situation awareness) refers to their understanding of different factors represented in the model. It refers to:

- Disturbance variety (negative events, DV) and their own capacity to deal with different disturbances (buffering capacity). Disturbances can affect all three domains (e.g. power loss that affects people in a municipality in general can also affect the variety of emergency management, for instance by disabling technical control or sensemaking systems (for instance telecommunications), or by affecting some actor that should have had an important control function.

- Outcomes of uncontrolled disturbances (tolerance). Interactions between control actions and disturbances can either results in normalization (successful control) or further disturbances. Misguided or failed control actions can also create new disturbances even without the added problem of external disturbances. The actors can anticipate or observe outcomes. 
- Sensemaking variety (SV) their capacity to understand how events and control actions interact to control disturbances or to propagate or create new disturbances, the "Table", see Ashby (1956). This includes, for instance, knowledge about effects on technical systems of disturbances and effects of interventions to keep them going. It regards the ability to predict the tolerance of the system in the face of a disturbance, and to anticipate problems and control them before they manifest. The manner in which people interact (respectful interaction) and relate to knowledge (wisdom) are analyzed, as well as timeliness of understanding (rapidity).

- Current understanding, functions, resources. People as sources of understanding (sensemaking resources), and the quality of their understanding (e.g. knowledge, experience, virtual role systems). Redundancy is analyzed. Sometimes help regarding sensemaking or control is given or received to/from other organizations, rather than through an adjustment of the own organization. Mendonca \& Wallace (2006) call such exchanges boundary spanning.

- Control variety (CV), embodied in their current strategies of control, their plans and resources. That includes how close they currently operate to some performance boundary (margin / robustness) It also includes their ability to alter their strategy (flexibility, bricolage) versus maintaining the strategy (stiffness) and how timely their acting is (rapidity).

\subsection{The three control domains}

The outer circle in Figure 5 represents sensemaking and control of ongoing events processes, of the emergency situation that needs to be controlled. 
The middle circle represents the technology variety (TV) that affects the overall ability of the actors to act on the events processes, rather than specific technologies that aim at specific disturbances. When working, it adds to the variety of the actors' sensemaking and control functions, but when malfunctioning, it adds to the variety of the unfolding events processes. The importance of information and communication infrastructure as well as disaster management tools have been emphasized in previous studies (e. g. Sarriegi et al., 2008; Thompson et al., 2006).

The inner circle represents sensemaking and control of the control process variety (the emergency management effort. On the one hand, it represents sensemaking of what functions are currently operating (sensemaking of current variety). There are at least four kinds of sensemaking roles (Wybo and Latiers, 2006). On the other hand, it represents control of functions, including the creation of new functions, detailed planning of how functions should work, and coordination between functions.

Functions in RESCOM are tasks or collections of tasks and sub-tasks that have outcomes that either attempt to exert control, or are outcomes of sensemaking efforts. Although the model does not describe command propagation in detail, as requested by previous research (Hamilton and Toh, 2010), it provides a context of what the actors are trying to achieve, of commands and information that needs to be propagated.

Woods includes cross-scale interactions as a factor for resilient action. That includes interactions between and within control domains. For instance, local decisions that affect the availability of resources for the whole effort, as well as high-level decisions that affect local availability of resources. 


\section{Analysis of the Rune exercise}

In this section we describe and analyze resiliency of disaster response for episodes in the exercise. In section 1, we sumamrize the exercise. In section 5.2- 5.4 we exemplify the main elements of RESCOM using excerpts from the scenario. In section 5.5 we show that the existing models had difficulties in describing resilience using the same excerpts.

\subsection{Excercise summary}

In what follows, we describe how RESCOM models overarching goals in terms of control domains.

Day 1. During the evening, day one, the operations manager informed the municipality manager about major imminent power outages, who then called in a management meeting for 08:00 the morning after at the city hall.

Day 2, at 08:00, the first management meeting started the day. Time of the next meeting was decided, as well as the time for a press conference. Just after the end of the meeting, the power outage spread, in accordance to the scenario.

At 10:00, the second meeting started. Time of the next meeting was decided, as well as the time for a press conference. Just after this meeting a helicopter crash accident occurred, in compliance with the scenario in the exercise.

At 13:00, the third meeting started. Time of the next meeting was decided, as well as the time for a press conference.

At 16:00, the fourth meeting started. After the meeting, work continued for a short while, followed by a debriefing session.

Summary of the exercise

The exercise illustrates the importance of modelling all three domains (functions, technologies, the events processes). The overarching goals of emergency work, set by the manager in the meet- 
ings, changed during the exercise. An important goal during day one was to establish an emergency management organization, a goal that was accomplished when the municipality manager called in a management meeting. Analyzed through RESCOM, accomplishing this goal affected the actors' control and sensemaking functions (the inner circle, figure 5). The goal setting during both days is analyzed as goal setting in COCOM, and as targeting in ECOM. In DOODA, the goals during both days are seen as an outcome of sensemaking, and the accomplishment as of the day one goal as plans and orders. During day two the first goal of the management team was to get an overview of the situation as a whole, not indicating a focus on any particular control domain in RESCOM. At the third meeting, the overarching goal was changed into the making of an organization with endurance. This goal regarded the endurance of the actors' control and sensemaking functions, rather than the events processes per se. This is an important distinction to make, since focusing on their own continued ability to function is qualitatively different from focusing on dealing with the events processes at large. The ability to adjust and maintain their own ability is vital for resilience, and thus important to model, as it affects both buffering capacity and margin. The distinction between control domains is not explicit in DOODA or COCOM/ECOM.

\subsection{Sensemaking and control of the ongoing events processes}

Five episodes illustrate how RESCOM can be used to analyze properties of resilience in the context of sensemaking and control of the events processes.

Excerpt 2 a (meeting three, 1 minute) "... since 10:45 when the wind was waning and the out-

look -7 degrees. After you left, we received information that a helicopter had crashed at Vånga

(comment: the only place where electricity lines entered the municipality). This meant that all

of Kinda (comment: the entire municipality) lost electricity. Those two in the helicopter were 
killed. We are also missing three people in a house that caught fire when the helicopter crashed"

Excerpt 2b (meeting two, 10 minutes) "I can add some information from last conversation we had when Anders reviewed the situation. Regarding state highway 34, the National Road Administration clears it up from Kisa to Hornkorset, and also road 135 from Hornkorset to Hycklige. They are clearing that up. One person was stuck at Rumma, that person has been rescued. But help has not reached the elderly home care staff that was stuck in a car. And I wrote that it was Kleveberget, Tidersrum. And then it was up the road to Högtomta. The Kisa emergency services are clearing that. There are a lot of trees there now, according to Waldau. A milk tanker is stuck somewhere at Flytthem. No one has been sent to take care of that yet. The road is also blocked between Horn and Hycklinge."

Excerpt $2 a$ and $2 b$. Sensemaking and control of the ongoing events processes

To model resilience and control it is important to distinguish between different effects of disturbances. Regarding control and sensemaking of the events processes, in excerpt $2 \mathrm{a}$ an actor described uncontrolled disturbances (DV) (wind, a helicopter going down, temperatures). In turn, they resulted in new disturbances (DV) (house on fire, loss of electricity) that needed to be controlled or result in further consequences. In RESCOM, this is described as disturbances to the event's process (rather than to their own functions or technologies for responding to the situation).

In Excerpt $2 b$ an actor described secondary effects of the uncontrolled wind meeting the environment, as well as what actors were doing about it. Analyzed through RESCOM, this exchange presents information important to decide whether functions are sufficient (control variety) versus events (disturbance variety). It is thus information important to decide whether the actors functions need to be attuned to the events process (whether they need to be resilient). Their sense- 
making practice enabling resilience, to share information, would be characterized as respectful interaction.

Excerpt 2c (work in smaller groups) "If you remember what it was like during Gudrun and Per (comment: names of previous major storms), then write down the names of the farms that were in need of water. And then they have to follow our timetable."

Excerpt 2c. Sensemaking and control of the ongoing events processes

To explain why the actors were resilient, it can be useful to differentiate between qualitatively different kinds of knowledge about disturbances and control activities. Drawing on previous experiences of similar events can be exemplified by excerpt 2c. To control the current event, the actors drew on previous experience of system tolerance to anticipate needs of water delivery. In contrast, in excerpts $2 \mathrm{~d}$ and $2 \mathrm{e}$ (below), the actors instead drew on knowledge about the mechanisms that determine outcomes of control actions (the "table" in Figure 4) to make an educated guess about future events (tolerance).

(meeting four, 22 minutes) "There are two fuel boilers in Bergdala. But they must also have back-up. (Someone: we have the large one there (comment: the large electricity generator)) They must have another boiler at the generator station at which they operate boilers and provide heat. Otherwise there will be no heat.“

(... Continued discussion and sensemaking about heating...)

"Need for power generators, we need to know how many power generators are needed."

"Then the question is how many do we need to heat up these places."

"More generators."

"More generators, yes."

"We will make a phone call." 
A sensemaking episode where the actors attempted to keep municipality heating systems working illustrates how RESCOM helps analyzing resilience (excerpt 2d). Firstly they attempted to make sense of the situation. In terms of the basic control loop (Figure 4), the sensemaking resource who initiated the episode was an expert (played by the exercise staff). He explained how the heating system worked and how it related to their current strategy for heating, to use power generators to drive systems (the "table", figure 4). The power generators were the main resource for their control strategy. He explained the outcome of the current situation if no intervention was done (that the heating system would stop working). In terms of resilience factors, their sensemaking was about the outcome of the current situation, complete loss of heating at the site discussed (tolerance). Together, they discussed the margin of their current control strategy versus the "table" (how things work), concluding that they needed more generators for their current strategy to work. That also regarded their general preparedness to cope with electricity loss (buffering capacity of the control strategy). Their control action was to initiate an activity (through a phone call) to get more generators. Resilience of their work can be characterized as preserving their current control strategy (stiffness) by increasing their buffering capacity and margin through boundary spanning.

(meeting four, 6 minutes) "Wastewater is not a priority. We will have an overflow, probably during the night. And we checked where overflows could happen, which could be at many places in the populated areas. And the most alarming one is at Rimforsa where we have two pumping plants near the water intake. So it will be monitored: and perhaps we need to prioritize it with backup generators. Staffan may take over if there is a problem. But we will look more closely at that. There may be problems if we pollute the drinking water." 
The actors also anticipated consequences of loss of control of the wastewater system (excerpt 2e). Described through RESCOM, they first made sense of the wastewater system, drawing on their knowledge of it (their source for sensemaking variety, buffering capacity versus the event) This allowed them to work in a feedforward manner, predicting future outcomes, the most important being pollution of their drinking water (tolerance). Making sense of possible interventions versus the disturbances (the "table" Figure 4) they described the system as being possible to restore partially, at specific points, rather than being an all-or-nothing system (tolerance). The actors subsequently planned control actions, in particular the usage of resources (power generators) to restore some functionality. They thought that more electricity generators might be needed, something that could affect other functions (cross-scale interactions). They were drawing on expertise as their main resource for sensemaking. They had a critical stance while drawing on their previous knowledge (wisdom). Their sensemaking operated in feedforward mode drawing on their knowledge of the "table", of buffering capacity (what they could do) versus disturbance variety (what might happen). Resilience of their work can be characterized as preserving the current strategy of using electricity generators to restore selected functionality (stiffness), possibly at the cost of other needs (cross-scale interactions).

\subsection{Sensemaking and control of actors' sensemaking and control functions}

The actors adjusted their own control and sensemaking variety in response to the ongoing events, exhibiting resilience. Some adjustments went beyond plans made in advance.

Excerpt 3a (meeting three, 11 minutes) Interruption: "Practical question. It there a power out-

age everywhere except here in this building? "

Spontaneous answer: "Not yet, but there is a risk. Now it's west of Kisa " 
Excerpt 3b (meeting two, 3 minutes) " What have we done. Let's see... First, we have not

checked up with E-ON (comment: the main electricity company) "

Interruption: " We've been checking up with them now."

Excerpt $3 a$ and $3 b$. Sensemaking as a collective effort

To analyze resilience, it is important to analyze vulnerability, how variety relies on individuals and collective efforts. Sensemaking variety in the meetings in the exercise sometimes depended on individual actors, and sometimes on interactions between actors. Sensemaking in the meetings was at large composed of statements such as excerpt $2 \mathrm{~b}$, with an actor describing events and functions. But there were often spontaneous answers or interruptions that clarified or questioned, or added to the information (see excerpt $3 \mathrm{a}$ and $3 \mathrm{~b}$ ), exemplifying respectful interaction. The locus of knowledge in one actor (excerpt 2e), several actors (excerpt 2c) and initially on one actor but later a joint effort (excerpt 2d), illustrates buffering capacity. Disturbances that make individuals unavailable - perhaps because they need rest, or perhaps they are not available at all next time they would have been needed, would cause a loss of control and sensemaking variety.

Excerpt 3c (meeting one, 13 minutes) ”Accessibility of roads, who has an eye on it? “

- "That's us too, we have had phone calls about those where there is trouble). That is also a task

for the Road Administration. Some work to find out more on this."

Excerpt 3d (meeting one, 14 minutes) $" \ldots$ is responsible for keeping track of power outages and road accessibility. And immediately takes contact with TA and posts it on the Kinda network (comment: web) so that we can reach out with our information that way." Excerpt $3 c$ and $3 d$. Sensemaking of actors' functions and adjusting actors' functions 
During the meetings the actors made sense of what functions they were currently performing.

Described through RESCOM, in excerpt 3c, they made sense of whether someone was performing the sensemaking function of monitoring roadblocks. In excerpt $3 \mathrm{~d}$, control was exercised by assigning (and thereby creating) the function of sensemaking of electricity loss to the same actor who already monitored roads (the added work potentially affecting the margin of other functions involving that actor). They exhibited resilience (flexibility) by changing their response to match disturbances. Their adjustment changed the variety of the actors' sensemaking in the events process, increasing their buffering capacity to include sensemaking of roadblocks.

\subsection{Sensemaking and control of technologies for sensemaking and control}

The actors' use and modification of technologies appeared to affect their resilience. Their technologies were also affected by disturbances, challenging their resilience.

(Work in a small group, shortly after the first staff meeting) "I'm thinking, if people enter in and want to read. If we are to be replaced later. If we think that we should keep up the work for a long time (backed up in the background by others), then of course we should not have to talk them through all that has happened, everything that we have been talking about for seven hours. Then they can go and read about what happened (someone: then we need not update them)

Someone: Then it must be short notes really or else it will be ... (Agreement voiced in the background).

Someone: But if we make two columns with time and staff information over there? "

(Interaction: Writes on the blackboard.)

"Events, what's done, and then you had the headings: what, who, time, and how."

"Should we not write this on paper blocks? Otherwise, won't it become very difficult later?"

Someone: Yes, which is best? 
Someone: "Yes, I prefer to write on the sheets. If you start like that you cannot move them on later."

Excerpt 4a. Creation of the "wall"

The actors designed two sensemaking tools for use in the management room during the first minutes of staff work. They designed a "wall" (see figure 6, and excerpt 4a) of notes of events and decisions, and a more efficient way of working with a log of events and decisions. The wall was visible to all actors in the room whereas only one actor at a time had access to the $\log$.

The actors intended the wall to be a place where new actors could go and read about events. Analyzed through RESCOM, the wall is a representation of their current understanding of events. It decreases the reliance on particular people to remember and tell others about events). In case someone would need to be replaced the effects would not be as dramatic on the system (potentially increasing tolerance). The wall was extensively used during management work to take note of and review events and decisions, apparently increasing the capacity of the team to keep track of events (buffering capacity). The design of the wall was achieved jointly, but with central input from two participants. The activity shows flexibility/bricolage. The excerpt does not show whether the wall would have occurred without those particular actors (tolerance), but it is a potential vulnerability.

To perform the log function, a person assuming the log function logged decisions and information in a computer. At the start of the exercise, it was predicted by an individual actor that capturing lots of simultaneous information through just listening and writing would be too difficult to manage. They then designed a way of working with the log to increase the amount of information the log writer could absorb simultaneously. It was a simple practice that people would have to provide small written notes with their information to the log function. Analysed in 
RESCOM, the log was a resource for understanding the situation, and the new way of working increased the margin of that work. The way of working with the log was designed (or described, if the participant had known about it beforehand) by one of the meeting participants. This presents a potential vulnerability, since the way of working with the log might not have been designed without this particular individual (tolerance). The activity shows flexibility/bricolage.

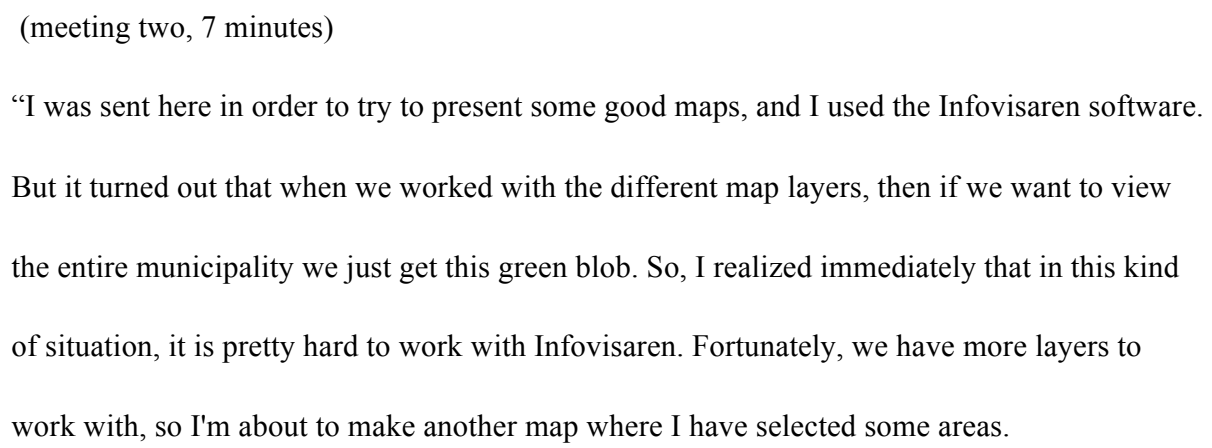

The episode in excerpt $4 \mathrm{~b}$ illustrates resilience with respect to a problematic technology. The staff attempted to use a geographic information system (GIS) to support their work, to maintain a map. They were surprised to discover that it was unsuitable for actual emergency work. Their map showed an indistinct green area, without information they needed for sensemaking of the ongoing event processes, e.g. information such as roads and electricity lines. The system became a problem, adding to the variety of the situation that the actors needed to control, rather than adding to the variety of the actors. One actor then got occupied with working on the GIS to see how 
it could be made more useful. This exemplifies going outside of prepared means (level 2 resilience). Analyzed through RESCOM, the change of the tool increased sensemaking variety of the events, and illustrates flexibility/bricolage. However, that one person got occupied with the task is also a vulnerability, since that decreases buffering capacity regarding the events at large, since that person then was partly busy with work on the system.

(meeting two, 36 minutes) "If email works, well, we mail to the group of headmasters, so it should work. But how does the Internet work? It works in Horn.

- "They may well have problems with electricity."

- "Horn may have problems with electricity."

- "They have generators."

- "I do not know how it is with fiber cables, but I suppose they have power?"

- "But if you sit in Horn's school and run power generators there, then there's power in the building. Then, email works?

- "If the network works."

- "Do they use wireless?"

- "There is no power"

- "I think it is very safe with SMS because it is ticking up directly in your phones. And we can also get confirmation."

- "But if there is a power failure, do the cellular networks function?"

- "No."

- "What we require is to get a confirmation that you received the SMS. If anyone does not confirm then we simply move on and see how we reach those who have not responded."

- "Mobile networks should have closed down now that electricity is gone."

- "I am not so sure about that, because there is standby power."

- Manager: "We take this issue with us to the small staff meeting.

- "But confirm that you received SMS. If we get no acknowledgment that means we must try to reach you in another way." 
There was also an incident with telecommunications technology that illustrates resilience. During excerpt $4 \mathrm{a}$, the actors failed to make sense of and anticipate how telecommunications would be affected by the storm. In RESCOM, that represents a failure to identify the tolerance of the telecommunications work. There were many different thoughts about how the system worked (the "table", figure 4), but no idea was accepted as correct. Several actors contributed to the sensemaking effort, but no consensus was reached. A sensemaking function was created in the smaller team to clarify the issue (figure 5, inner loop) (flexibility).

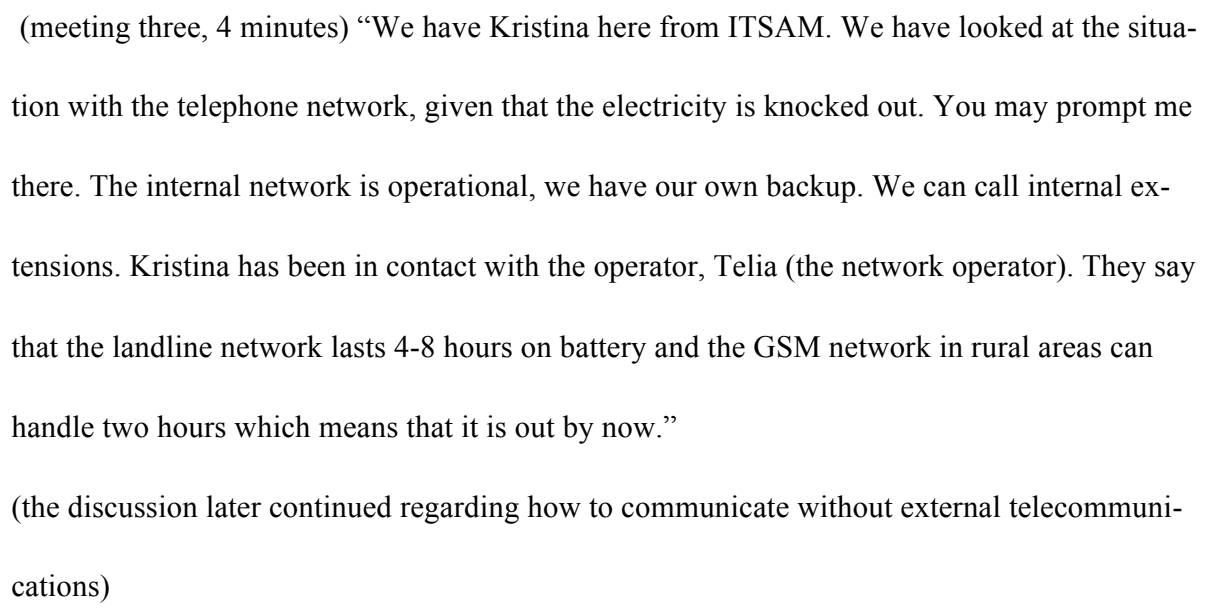

Excerpt 4d, Sensemaking of communications infrastructure.

Later (excerpt 4d), the actors had done the sensemaking work decided in excerpt 4c. Analyzed through RESCOM, it had been achieved by contacting the telecommunications provider (boundary spanning), as a source of sensemaking, to understand the "table" (Figure 4). They discovered that the communications infrastructure outside of the building had become unavailable some time ago (tolerance). A battery backup of the system, that had supported it for two hours after the loss of electricity, had also expired. They had missed the opportunity to use the backup to reorganize communications, after the unexpected but easily observed loss of electricity (lack of ra- 
pidity). This affected their resilience in a negative way, although in this particular situation it did not affect the outcome. The actors were able to make a transition from using mobile telephony to landline telephony that only worked in the particular building where they coordinated and controlled their actions (flexibility). But if the situation had been different, with a need to communicate with people at remote locations to create an alternative communications infrastructure, then it would have been advantageous to have requisite sensemaking variety already at the time of excerpt $4 \mathrm{c}$.

\subsection{Comparison with existing models}

We now proceed with describing the same features of the case study using elements of the existing models (where possible). The comparison of the models' application to the selected excerpts is presented in Table 1.

\begin{tabular}{|l|l|l|l|l|}
\hline $\begin{array}{l}\text { Ex- } \\
\text { cerp } \\
\text { ts }\end{array}$ & RESCOM & COCOM & ECOM & DOODA \\
\hline 2a & $\begin{array}{l}\text { Disturbances to the } \\
\text { events process. }\end{array}$ & $\begin{array}{l}\text { Feeback about } \\
\text { events, determi- } \\
\text { nation of out- } \\
\text { comes }\end{array}$ & $\begin{array}{l}\text { Monitoring } \\
\text { of events }\end{array}$ & $\begin{array}{l}\text { Input to sensemak- } \\
\text { ing from data col- } \\
\text { lection }\end{array}$ \\
\hline 2b & $\begin{array}{l}\text { Their way of work- } \\
\text { ing (respectful in- } \\
\text { teraction) enabling } \\
\text { sensemaking re- } \\
\text { garding the need } \\
\text { for being resilient } \\
\text { (to change the ac- } \\
\text { tors functions in } \\
\text { response to events) }\end{array}$ & $\begin{array}{l}\text { Opportunistic } \\
\text { mode - feed- } \\
\text { back driven, } \\
\text { with limited } \\
\text { planning is de- } \\
\text { scribed. }\end{array}$ & $\begin{array}{l}\text { A monitoring } \\
\text { activity, } \\
\text { keeping track } \\
\text { of current } \\
\text { progress and } \\
\text { reviewing } \\
\text { goals. }\end{array}$ & $\begin{array}{l}\text { A sensemaking ac- } \\
\text { tivity, describing } \\
\text { what needs to be } \\
\text { done, and review- } \\
\text { ing the current ac- } \\
\text { tivities for achiev- } \\
\text { ing the goals. }\end{array}$ \\
\hline $\begin{array}{l}\text { 2c } \\
\text { source of resil- } \\
\text { ience: Actors expe- } \\
\text { rience of previous } \\
\text { similar situations } \\
\text { was a factor affect- } \\
\text { ing their sensemak- } \\
\text { ing variety (of their }\end{array}$ & $\begin{array}{l}\text { COCOM would } \\
\text { identify that } \\
\text { they were able } \\
\text { to make sense of } \\
\text { the situation } \\
\text { (construct), and } \\
\text { describe that } \\
\text { this enabled }\end{array}$ & $\begin{array}{l}\text { ECOM } \\
\text { would treat } \\
\text { the construct } \\
\text { as COCOM } \\
\text { does, but then } \\
\text { analyze the } \\
\text { situation as a } \\
\text { monintoring }\end{array}$ & $\begin{array}{l}\text { Then outcome of } \\
\text { sensemaking } \\
\text { (needs of water de- } \\
\text { livery), and initia- } \\
\text { tion of planning of } \\
\text { water delivery } \\
\text { would be identi- } \\
\text { fied. }\end{array}$ \\
\hline
\end{tabular}




\begin{tabular}{|c|c|c|c|c|}
\hline $\begin{array}{l}\text { Ex- } \\
\text { cerp } \\
\text { ts }\end{array}$ & RESCOM & $\mathrm{COCOM}$ & ECOM & DOODA \\
\hline $2 a$ & $\begin{array}{l}\text { Disturbances to the } \\
\text { events process. }\end{array}$ & $\begin{array}{l}\text { Feeback about } \\
\text { events, determi- } \\
\text { nation of out- } \\
\text { comes }\end{array}$ & $\begin{array}{l}\text { Monitoring } \\
\text { of events }\end{array}$ & $\begin{array}{l}\text { Input to sensemak- } \\
\text { ing from data col- } \\
\text { lection }\end{array}$ \\
\hline $2 b$ & $\begin{array}{l}\text { Their way of work- } \\
\text { ing (respectful in- } \\
\text { teraction) enabling } \\
\text { sensemaking re- } \\
\text { garding the need } \\
\text { for being resilient } \\
\text { (to change the ac- } \\
\text { tors functions in } \\
\text { response to events) }\end{array}$ & $\begin{array}{l}\text { Opportunistic } \\
\text { mode - feed- } \\
\text { back driven, } \\
\text { with limited } \\
\text { planning is de- } \\
\text { scribed. }\end{array}$ & $\begin{array}{l}\text { A monitoring } \\
\text { activity, } \\
\text { keeping track } \\
\text { of current } \\
\text { progress and } \\
\text { reviewing } \\
\text { goals. }\end{array}$ & $\begin{array}{l}\text { A sensemaking ac- } \\
\text { tivity, describing } \\
\text { what needs to be } \\
\text { done, and review- } \\
\text { ing the current ac- } \\
\text { tivities for achiev- } \\
\text { ing the goals. }\end{array}$ \\
\hline \multirow[t]{2}{*}{$2 \mathrm{c}$} & $\begin{array}{l}\text { Events process } \\
\text { source of resil- } \\
\text { ience: Actors expe- } \\
\text { rience of previous } \\
\text { similar situations } \\
\text { was a factor affect- } \\
\text { ing their sensemak- } \\
\text { ing variety (of their }\end{array}$ & $\begin{array}{l}\text { COCOM would } \\
\text { identify that } \\
\text { they were able } \\
\text { to make sense of } \\
\text { the situation } \\
\text { (construct), and } \\
\text { describe that } \\
\text { this enabled }\end{array}$ & $\begin{array}{l}\text { ECOM } \\
\text { would treat } \\
\text { the construct } \\
\text { as COCOM } \\
\text { does, but then } \\
\text { analyze the } \\
\text { situation as a } \\
\text { monintoring }\end{array}$ & $\begin{array}{l}\text { The outcome of } \\
\text { sensemaking } \\
\text { (needs of water de- } \\
\text { livery), and initia- } \\
\text { tion of planning of } \\
\text { water delivery } \\
\text { would be identi- } \\
\text { fied. }\end{array}$ \\
\hline & $\begin{array}{l}\text { buffering capacity } \\
\text { versus the events). }\end{array}$ & $\begin{array}{l}\text { them to keep } \\
\text { control of the } \\
\text { event in tactical } \\
\text { mode (feed for- } \\
\text { ward) }\end{array}$ & $\begin{array}{l}\text { activity } \\
\text { (planning wa- } \\
\text { ter delivery) }\end{array}$ & \\
\hline $2 d$ & $\begin{array}{l}\text { Events process re- } \\
\text { silience strategy: } \\
\text { preserving their } \\
\text { current control } \\
\text { strategy (stiffness) } \\
\text { by increasing their } \\
\text { buffering capacity } \\
\text { and margin through } \\
\text { boundary spanning. }\end{array}$ & $\begin{array}{l}\text { Their quality of } \\
\text { control goes } \\
\text { from scrambled } \\
\text { to opportunistic } \\
\text { control mode, } \\
\text { based on an im- } \\
\text { proved construct } \\
\text { through feed- } \\
\text { back on the } \\
\text { situation. }\end{array}$ & $\begin{array}{l}\text { Monitoring } \\
\text { activity: Un- } \\
\text { derstanding } \\
\text { (the need for } \\
\text { generators) } \\
\text { and planning } \\
\text { (to make a } \\
\text { phone call). }\end{array}$ & $\begin{array}{l}\text { Highlight on a lack } \\
\text { of sensors sampling } \\
\text { the actual situation. } \\
\text { Outcomes of sen- } \\
\text { semaking (goal to } \\
\text { restore heating us- } \\
\text { ing electricity gen- } \\
\text { erators), outcome } \\
\text { of planning (make } \\
\text { a phone call). }\end{array}$ \\
\hline $2 \mathrm{e}$ & $\begin{array}{l}\text { Events process re- } \\
\text { silience strategy: A } \\
\text { critical stance dur- } \\
\text { ing sensemaking } \\
\text { (wisdom). Previous } \\
\text { experience affect- } \\
\text { ing sensemaking }\end{array}$ & $\begin{array}{l}\text { COCOM de- } \\
\text { scribes their } \\
\text { quality of con- } \\
\text { trol as strategic } \\
\text { since they dis- } \\
\text { cussed different } \\
\text { goals in feed- }\end{array}$ & $\begin{array}{l}\text { ECOM de- } \\
\text { scribes their } \\
\text { work as } \\
\text { monitoring } \\
\text { and targeting, } \\
\text { discussing } \\
\text { overarching }\end{array}$ & $\begin{array}{l}\text { Outcomes of the } \\
\text { sensemaking activ- } \\
\text { itiy (prevent pollu- } \\
\text { tion of the drinking } \\
\text { water). They also } \\
\text { present aspects } \\
\text { critical to planning }\end{array}$ \\
\hline
\end{tabular}




\begin{tabular}{|c|c|c|c|c|}
\hline $\begin{array}{l}\text { Ex- } \\
\text { cerp } \\
\text { ts }\end{array}$ & RESCOM & $\mathrm{COCOM}$ & ECOM & DOODA \\
\hline $2 a$ & $\begin{array}{l}\text { Disturbances to the } \\
\text { events process. }\end{array}$ & $\begin{array}{l}\text { Feeback about } \\
\text { events, determi- } \\
\text { nation of out- } \\
\text { comes }\end{array}$ & $\begin{array}{l}\text { Monitoring } \\
\text { of events }\end{array}$ & $\begin{array}{l}\text { Input to sensemak- } \\
\text { ing from data col- } \\
\text { lection }\end{array}$ \\
\hline $2 b$ & $\begin{array}{l}\text { Their way of work- } \\
\text { ing (respectful in- } \\
\text { teraction) enabling } \\
\text { sensemaking re- } \\
\text { garding the need } \\
\text { for being resilient } \\
\text { (to change the ac- } \\
\text { tors functions in } \\
\text { response to events) }\end{array}$ & $\begin{array}{l}\text { Opportunistic } \\
\text { mode - feed- } \\
\text { back driven, } \\
\text { with limited } \\
\text { planning is de- } \\
\text { scribed. }\end{array}$ & $\begin{array}{l}\text { A monitoring } \\
\text { activity, } \\
\text { keeping track } \\
\text { of current } \\
\text { progress and } \\
\text { reviewing } \\
\text { goals. }\end{array}$ & $\begin{array}{l}\text { A sensemaking ac- } \\
\text { tivity, describing } \\
\text { what needs to be } \\
\text { done, and review- } \\
\text { ing the current ac- } \\
\text { tivities for achiev- } \\
\text { ing the goals. }\end{array}$ \\
\hline \multirow[t]{2}{*}{$2 \mathrm{c}$} & $\begin{array}{l}\text { Events process } \\
\text { source of resil- } \\
\text { ience: Actors expe- } \\
\text { rience of previous } \\
\text { similar situations } \\
\text { was a factor affect- } \\
\text { ing their sensemak- } \\
\text { ing variety (of their }\end{array}$ & $\begin{array}{l}\text { COCOM would } \\
\text { identify that } \\
\text { they were able } \\
\text { to make sense of } \\
\text { the situation } \\
\text { (construct), and } \\
\text { describe that } \\
\text { this enabled }\end{array}$ & $\begin{array}{l}\text { ECOM } \\
\text { would treat } \\
\text { the construct } \\
\text { as COCOM } \\
\text { does, but then } \\
\text { analyze the } \\
\text { situation as a } \\
\text { monintoring }\end{array}$ & $\begin{array}{l}\text { The outcome of } \\
\text { sensemaking } \\
\text { (needs of water de- } \\
\text { livery), and initia- } \\
\text { tion of planning of } \\
\text { water delivery } \\
\text { would be identi- } \\
\text { fied. }\end{array}$ \\
\hline & $\begin{array}{l}\text { buffering capacity } \\
\text { versus the events). }\end{array}$ & $\begin{array}{l}\text { them to keep } \\
\text { control of the } \\
\text { event in tactical } \\
\text { mode (feed for- } \\
\text { ward) }\end{array}$ & $\begin{array}{l}\text { activity } \\
\text { (planning wa- } \\
\text { ter delivery) }\end{array}$ & \\
\hline $2 d$ & $\begin{array}{l}\text { Events process re- } \\
\text { silience strategy: } \\
\text { preserving their } \\
\text { current control } \\
\text { strategy (stiffness) } \\
\text { by increasing their } \\
\text { buffering capacity } \\
\text { and margin through } \\
\text { boundary spanning. }\end{array}$ & $\begin{array}{l}\text { Their quality of } \\
\text { control goes } \\
\text { from scrambled } \\
\text { to opportunistic } \\
\text { control mode, } \\
\text { based on an im- } \\
\text { proved construct } \\
\text { through feed- } \\
\text { back on the } \\
\text { situation. }\end{array}$ & $\begin{array}{l}\text { Monitoring } \\
\text { activity: Un- } \\
\text { derstanding } \\
\text { (the need for } \\
\text { generators) } \\
\text { and planning } \\
\text { (to make a } \\
\text { phone call). }\end{array}$ & $\begin{array}{l}\text { Highlight on a lack } \\
\text { of sensors sampling } \\
\text { the actual situation. } \\
\text { Outcomes of sen- } \\
\text { semaking (goal to } \\
\text { restore heating us- } \\
\text { ing electricity gen- } \\
\text { erators), outcome } \\
\text { of planning (make } \\
\text { a phone call). }\end{array}$ \\
\hline $2 \mathrm{e}$ & $\begin{array}{l}\text { Events process re- } \\
\text { silience strategy: A } \\
\text { critical stance dur- } \\
\text { ing sensemaking } \\
\text { (wisdom). Previous } \\
\text { experience affect- } \\
\text { ing sensemaking }\end{array}$ & $\begin{array}{l}\text { COCOM de- } \\
\text { scribes their } \\
\text { quality of con- } \\
\text { trol as strategic } \\
\text { since they dis- } \\
\text { cussed different } \\
\text { goals in feed- }\end{array}$ & $\begin{array}{l}\text { ECOM de- } \\
\text { scribes their } \\
\text { work as } \\
\text { monitoring } \\
\text { and targeting, } \\
\text { discussing } \\
\text { overarching }\end{array}$ & $\begin{array}{l}\text { Outcomes of the } \\
\text { sensemaking activ- } \\
\text { itiy (prevent pollu- } \\
\text { tion of the drinking } \\
\text { water). They also } \\
\text { present aspects } \\
\text { critical to planning }\end{array}$ \\
\hline
\end{tabular}




\begin{tabular}{|c|c|c|c|c|}
\hline $\begin{array}{l}\text { Ex- } \\
\text { cerp } \\
\text { ts }\end{array}$ & RESCOM & $\mathrm{COCOM}$ & ECOM & DOODA \\
\hline $2 a$ & $\begin{array}{l}\text { Disturbances to the } \\
\text { events process. }\end{array}$ & $\begin{array}{l}\text { Feeback about } \\
\text { events, determi- } \\
\text { nation of out- } \\
\text { comes }\end{array}$ & $\begin{array}{l}\text { Monitoring } \\
\text { of events }\end{array}$ & $\begin{array}{l}\text { Input to sensemak- } \\
\text { ing from data col- } \\
\text { lection }\end{array}$ \\
\hline $2 b$ & $\begin{array}{l}\text { Their way of work- } \\
\text { ing (respectful in- } \\
\text { teraction) enabling } \\
\text { sensemaking re- } \\
\text { garding the need } \\
\text { for being resilient } \\
\text { (to change the ac- } \\
\text { tors functions in } \\
\text { response to events) }\end{array}$ & $\begin{array}{l}\text { Opportunistic } \\
\text { mode - feed- } \\
\text { back driven, } \\
\text { with limited } \\
\text { planning is de- } \\
\text { scribed. }\end{array}$ & $\begin{array}{l}\text { A monitoring } \\
\text { activity, } \\
\text { keeping track } \\
\text { of current } \\
\text { progress and } \\
\text { reviewing } \\
\text { goals. }\end{array}$ & $\begin{array}{l}\text { A sensemaking ac- } \\
\text { tivity, describing } \\
\text { what needs to be } \\
\text { done, and review- } \\
\text { ing the current ac- } \\
\text { tivities for achiev- } \\
\text { ing the goals. }\end{array}$ \\
\hline \multirow[t]{2}{*}{$2 \mathrm{c}$} & $\begin{array}{l}\text { Events process } \\
\text { source of resil- } \\
\text { ience: Actors expe- } \\
\text { rience of previous } \\
\text { similar situations } \\
\text { was a factor affect- } \\
\text { ing their sensemak- } \\
\text { ing variety (of their }\end{array}$ & $\begin{array}{l}\text { COCOM would } \\
\text { identify that } \\
\text { they were able } \\
\text { to make sense of } \\
\text { the situation } \\
\text { (construct), and } \\
\text { describe that } \\
\text { this enabled }\end{array}$ & $\begin{array}{l}\text { ECOM } \\
\text { would treat } \\
\text { the construct } \\
\text { as COCOM } \\
\text { does, but then } \\
\text { analyze the } \\
\text { situation as a } \\
\text { monintoring }\end{array}$ & $\begin{array}{l}\text { The outcome of } \\
\text { sensemaking } \\
\text { (needs of water de- } \\
\text { livery), and initia- } \\
\text { tion of planning of } \\
\text { water delivery } \\
\text { would be identi- } \\
\text { fied. }\end{array}$ \\
\hline & $\begin{array}{l}\text { buffering capacity } \\
\text { versus the events). }\end{array}$ & $\begin{array}{l}\text { them to keep } \\
\text { control of the } \\
\text { event in tactical } \\
\text { mode (feed for- } \\
\text { ward) }\end{array}$ & $\begin{array}{l}\text { activity } \\
\text { (planning wa- } \\
\text { ter delivery) }\end{array}$ & \\
\hline $2 d$ & $\begin{array}{l}\text { Events process re- } \\
\text { silience strategy: } \\
\text { preserving their } \\
\text { current control } \\
\text { strategy (stiffness) } \\
\text { by increasing their } \\
\text { buffering capacity } \\
\text { and margin through } \\
\text { boundary spanning. }\end{array}$ & $\begin{array}{l}\text { Their quality of } \\
\text { control goes } \\
\text { from scrambled } \\
\text { to opportunistic } \\
\text { control mode, } \\
\text { based on an im- } \\
\text { proved construct } \\
\text { through feed- } \\
\text { back on the } \\
\text { situation. }\end{array}$ & $\begin{array}{l}\text { Monitoring } \\
\text { activity: Un- } \\
\text { derstanding } \\
\text { (the need for } \\
\text { generators) } \\
\text { and planning } \\
\text { (to make a } \\
\text { phone call). }\end{array}$ & $\begin{array}{l}\text { Highlight on a lack } \\
\text { of sensors sampling } \\
\text { the actual situation. } \\
\text { Outcomes of sen- } \\
\text { semaking (goal to } \\
\text { restore heating us- } \\
\text { ing electricity gen- } \\
\text { erators), outcome } \\
\text { of planning (make } \\
\text { a phone call). }\end{array}$ \\
\hline $2 \mathrm{e}$ & $\begin{array}{l}\text { Events process re- } \\
\text { silience strategy: A } \\
\text { critical stance dur- } \\
\text { ing sensemaking } \\
\text { (wisdom). Previous } \\
\text { experience affect- } \\
\text { ing sensemaking }\end{array}$ & $\begin{array}{l}\text { COCOM de- } \\
\text { scribes their } \\
\text { quality of con- } \\
\text { trol as strategic } \\
\text { since they dis- } \\
\text { cussed different } \\
\text { goals in feed- }\end{array}$ & $\begin{array}{l}\text { ECOM de- } \\
\text { scribes their } \\
\text { work as } \\
\text { monitoring } \\
\text { and targeting, } \\
\text { discussing } \\
\text { overarching }\end{array}$ & $\begin{array}{l}\text { Outcomes of the } \\
\text { sensemaking activ- } \\
\text { itiy (prevent pollu- } \\
\text { tion of the drinking } \\
\text { water). They also } \\
\text { present aspects } \\
\text { critical to planning }\end{array}$ \\
\hline
\end{tabular}




\begin{tabular}{|l|l|l|l|}
\hline $\begin{array}{l}\text { semaking (contact- } \\
\text { ing telecommun- } \\
\text { ciations provider). } \\
\text { Missed opportunity } \\
\text { to use the backup } \\
\text { to reorganize } \\
\text { communications, } \\
\text { after the unex- } \\
\text { pected but easily } \\
\text { observed loss of } \\
\text { action (transi- } \\
\text { tion to alterna- } \\
\text { tive technol- } \\
\text { ogy). }\end{array}$ & $\begin{array}{l}\text { loop. } \\
\text { ness of resilience: } \\
\text { lack of rapidity). } \\
\text { Transition to alter- } \\
\text { native technology } \\
\text { (flexibility). }\end{array}$ & $\begin{array}{l}\text { restore communi- } \\
\text { cations, and orders } \\
\text { to implement it. }\end{array}$ \\
\hline
\end{tabular}

Table 1. Comparison of COCOM, ECOM, DOODA, and RESCOM for analyzing the Rune exercise

Comparing the different models (table 1), excerpt 2a describes disturbances, an analysis where RESCOM in contrast to the other models describes that it focuses on need for control and resilience versus the events process rather than on other processes. In excerpt $2 b$ and $2 c$ RESCOM identifies factors affecting their ability to understand events. In excerpts $2 \mathrm{~d}$ and $2 \mathrm{e}$, RESCOM identifies their strategies for being resilient in situations that exceeds (2d) or and threatens to exceed (2e) their current capacity. The analysis of excerpts $2 \mathrm{~b}$ to $2 \mathrm{e}$ shows that the CO$\mathrm{COM} / \mathrm{ECOM} / \mathrm{DOODA}$ analyses add detail to the sensemaking and control descriptions, but do not describe resilience.

In excerpts $3 \mathrm{a}$ and $3 \mathrm{~b}$, RESCOM analyzes vulnerability, how resilience draws on particular individuals and collective efforts. COCOM and DOODA do not focus on those issues. COCOM, ECOM and DOODA do describe aspects of control in excerpts $3 \mathrm{c}$ and $3 \mathrm{~d}$. But they were doing more than just setting goals, adjusting their construct, deciding and ordering actions, and making plans. They were adjusting the scope of the events processes that they addressed, and their means 
for acting. They were assigning responsibilities for functions to people, attuning their variety to the variety of the ongoing event. They were engaged in controlling and making sense of their own processes of control.

In excerpts $4 \mathrm{a}$ and regarding the log, the RESCOM analysis shows how changing their sensemaking and control technologies affects their ability to control events, ie. how it affects resilience. RESCOM also identifies potential vulnerabilities of relying on individuals. COCOM and ECOM omits the design activities that are the sources of resilience, but notes observable effects of the practices and tools on ability to control, when they are already in place. Regarding problems with technologies, in excerpts $4 \mathrm{c}$ and 4d, RESCOM characterises resilience as well as describes vulnerabilities whereas COCOM and ECOM focuses on describing quality of control and control mode. DOODA describes effects on different functions and relations between them in excerpts $4 \mathrm{a}-4 \mathrm{~d}$.

\section{Conclusions}

In this article we have used a case study to illustrate the application of a model for resilient sensemaking and control of irregular negative events, RESCOM. As illustrated in this paper, RESCOM can help to identify resilience building processes and sources of resilient emergency response in the context of sensemaking and control activities. Factors of resilience (e.g. buffering capacity, tolerance, margin, flexibility, cross-scale interactions, boundary spanning), as described by Woods (2006), Mendonca \& Wallace (2006), (Kendra and Wachtendorf, 2003) and (Weick, 1993), are included in the model. In the model, the factors are directly related to what the actors do to control the situation and to adjust their ability to act, as well as what sources of resilience they draw on to make sense of the situation. 
The goal of RESCOM is to analyze resilience. If other aspects are also in focus, e.g. quality of control (as in COCOM) then one can use our model in conjunction with the existing models. Important future work with regard to RESCOM is more in-depth modelling of cross-scale interactions and boundary spanning. More specifically, one could model coordination between actors that collaborate more loosely than they did in the current exercise, where actors from different organizations in the municipality were sitting together in management meetings.

Evaluation of resilience in an exercise is another important topic. The current analysis allows identification of potential vulnerabilities and weaknesses of measures to create resilience (e.g. see Table 1, excerpt $4 \mathrm{~b}, 4 \mathrm{~d})$, but it is insufficient to evaluate their resilience in depth. To do that, the analysis must include aspects such as alternative courses of action (what else could they have done, compared to what they actually did? what could have enabled them to discover that course of action?).

\section{Acknowledgements}

This study was sponsored by the Swedish Civil Contingencies Agency. We are also indebted to

the planners and participants in the exercise for being allowed to visit, observe, and record the exercise.

\section{References}

Artman, H. (1999) Fördelade kunskapsprocesser i ledningscentraler vid nödsituationer - koordination och situationsmedvetenhet $\mathrm{PhD}$ thesis. Linköping University, Linköping, Sweden.

Ashby, W.R. (1956) An introduction to cybernetics. London: Chapnam \& Hall.

Brehmer, B. (2007) 'Understanding the functions of C2 is the key to progress', The International C2 Journal, Vol. 1, No. 1, pp. 211-232.

Comfort, K. (1996) Self organization in disaster response: the great Hanshin, Japan earthquake of January 17, 1995 No. 78, The Natural Hazards Center, University of Colorado at Boulder, Boulder, CO. 
Lundberg, J., Törnqvist, E. and Nadjm-Tehrani, S. (2012) Resilience in Sensemaking and Control of Emergency Response International Journal of Emergency Management, vol 8 no 2, p 99 - 122. DOI: 10.1504/IJEM.2012.046009

Endsley, M.R. (1988) 'Situation awareness global assessment technique (SAGAT)': Proceedings of the National Aerospace and Electronics Conference (NAECON), IEEE, Dayton, OH pp. 789-795.

Hamilton, A. and Toh, K.K.T. (2010) 'A review of emergency organisations: the need for a theoretical framework', International Journal of Emergency Management, Vol. 7, No. 2, pp. $111-123$.

Hollnagel, E. (2000) 'Modeling the Orderliness of Human Action', in Sarter, N.B. and Amalberti, R. (Eds.): Cognitive engineering in the aviation domain, Lawrence Erlbaum Associates, Mahwah, NJ, pp. 65-98.

Hollnagel, E. and Woods, D.A. (2005) Joint cognitive systems: foundations of cognitive systems engineering. Boca Raton, FL: CRC Press.

Kendra, J. and Wachtendorf, T. (2003) 'Elements of resilience after the World Trade Center disaster: reconstituting New York City's emergency operations centre', Disasters, Vol. 27, No. 1, pp. 37-53.

Lundberg, J. (2002) 'Operationalising civil pilot's process of understanding instrument failure events': Humans in a complex environment Proceedings of the 34th Annual Congress of the Nordic Ergonomics Society, Kålmården, Sweden, pp. 569-574.

Manyena, S.B. (2006) 'The concept of resilience revisited', Disasters, Vol. 30, No. 4, pp. 434450.

Mendonca, D. and Wallace, W.A. (2006) 'Adaptive Capacity: Electric Power Restoration in New York City Following the 11 September 2001 Attacks': Proceedings of 2nd Resilience Engineering Symposium Juan-les-Pins, France, pp. 209-219.

Neisser, U. (1976) Cognition and Reality: Principles and implications of cognitive psychology. San Fransisco: W H Freeman and Company.

Sarriegi, J.M., Sveen, F.O., Torres, J.M. and Gonzalez, J.J. (2008) 'Towards a research framework for critical infrastructure interdependencies', International Journal of Emergency Management, Vol. 5, No. 3-4, pp. 235-249.

Smith, K. and Hancock, P.A. (1995) 'Situation Awareness Is Adaptive, Externally Directed Consciousness', Human Factors, Vol. 37, No. 1, pp. 137-148.

Tenney, Y.J., Adams, M.J., Pew, R.W., Huggins, A.W. and Rogers, W.H. (1992) A principled approach to the measurement of situation awareness in commercial aviation No. NASA contractor report 4451, Langley Research Center: NASA.

Thompson, S., Altay, N., Green III, W.G. and Lapetina , J. (2006) 'Improving disaster response efforts with decision support systems', International Journal of Emergency Management, Vol. 3, No. 4, pp. 250-263.

Weick, K. (1993) 'The collapse of sensemaking in organizations: The Mann Gulch disaster.', Administrative Science Quarterly, Vol. 38, No. 4.

Weick, K. (1995) Sensemaking in organizations. Thousand Oaks, CA: Sage.

Weick, K. (2001) Making sense of the organization. Malden, MA: Blackwell publishing.

Weick, K.E. and Sutcliffe, K.M. (2007) Managing the unexpected: resilient performance in an age of uncertainty. San Fransisco, CA: Jossey-Bass.

Woods, D. (2006) 'Essential Characteristics of Resilience', in Hollnagel, E., Woods, D. and Leveson, N. (Eds.): Resilience Engineering: Concepts and Precepts, Ashgate, Aldershot, UK, pp. 21-34.

Wybo , J.-L. and Latiers, M. (2006) 'Exploring complex emergency situations' dynamic: theoretical, epistemological and methodological proposals', International Journal of Emergency Management, Vol. 3, No. 1, pp. 40-51. 


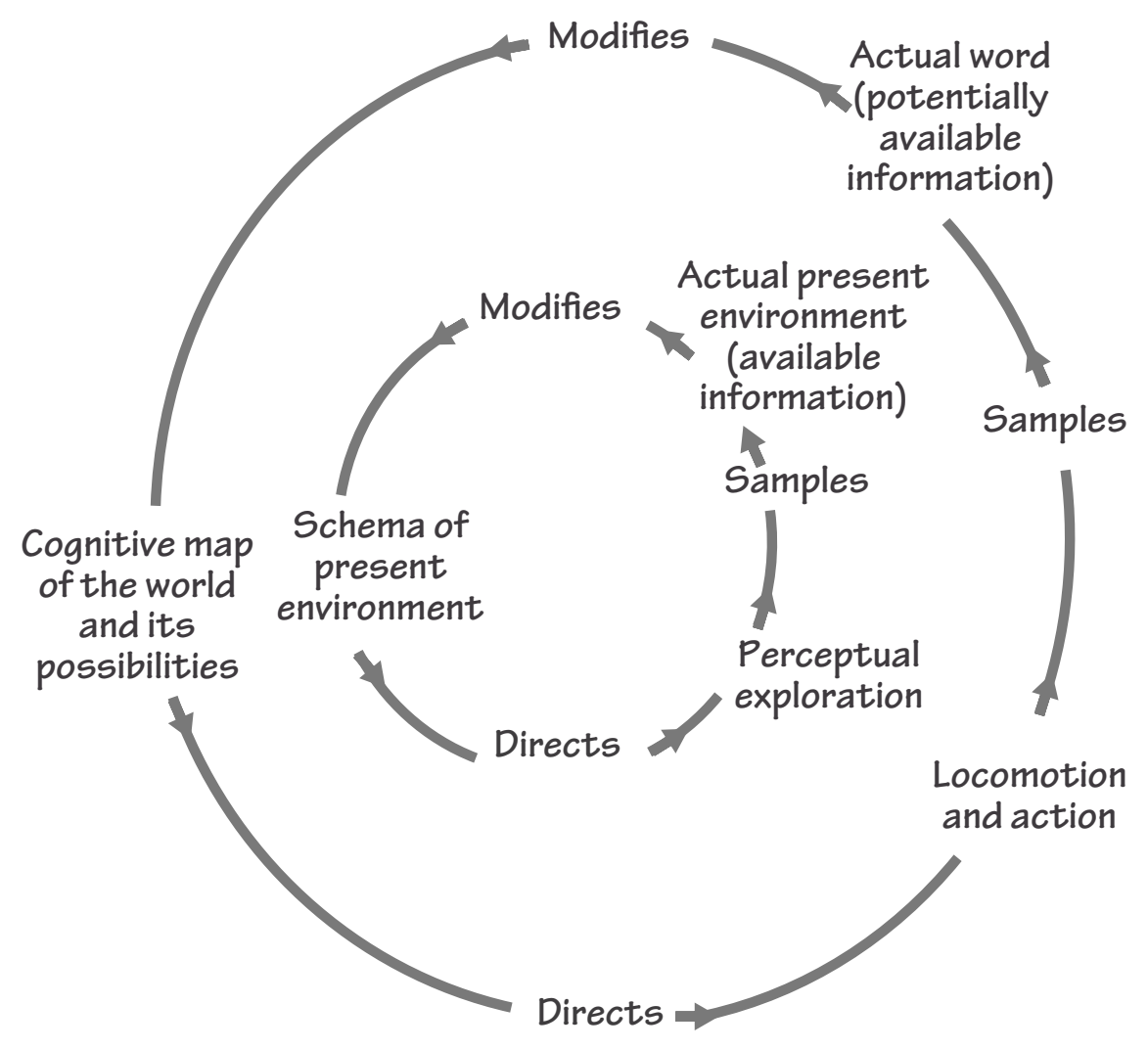

Figure 1. The Perceptual Cycle, adapted from Neisser (1976). Arrows indicate the direction of the cyclical flow of events. 


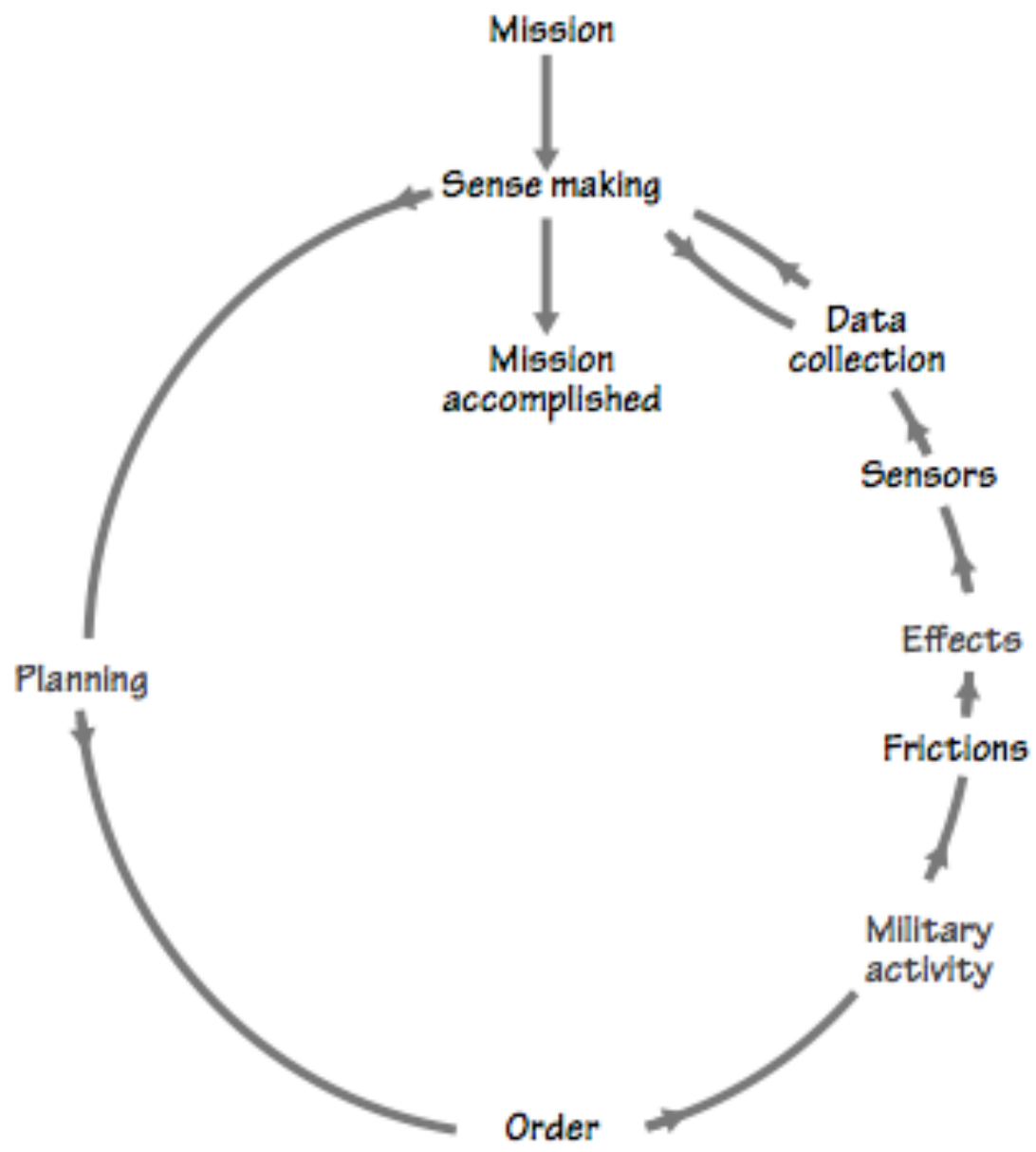

Figure 2. The Dynamic Observe, Orient, Decide, and Act (DOODA) loop for military command and control. (adapted from Brehmer, 2007). The arrows and their directions represent preconditions for what follows, rather than representing temporal relations. 


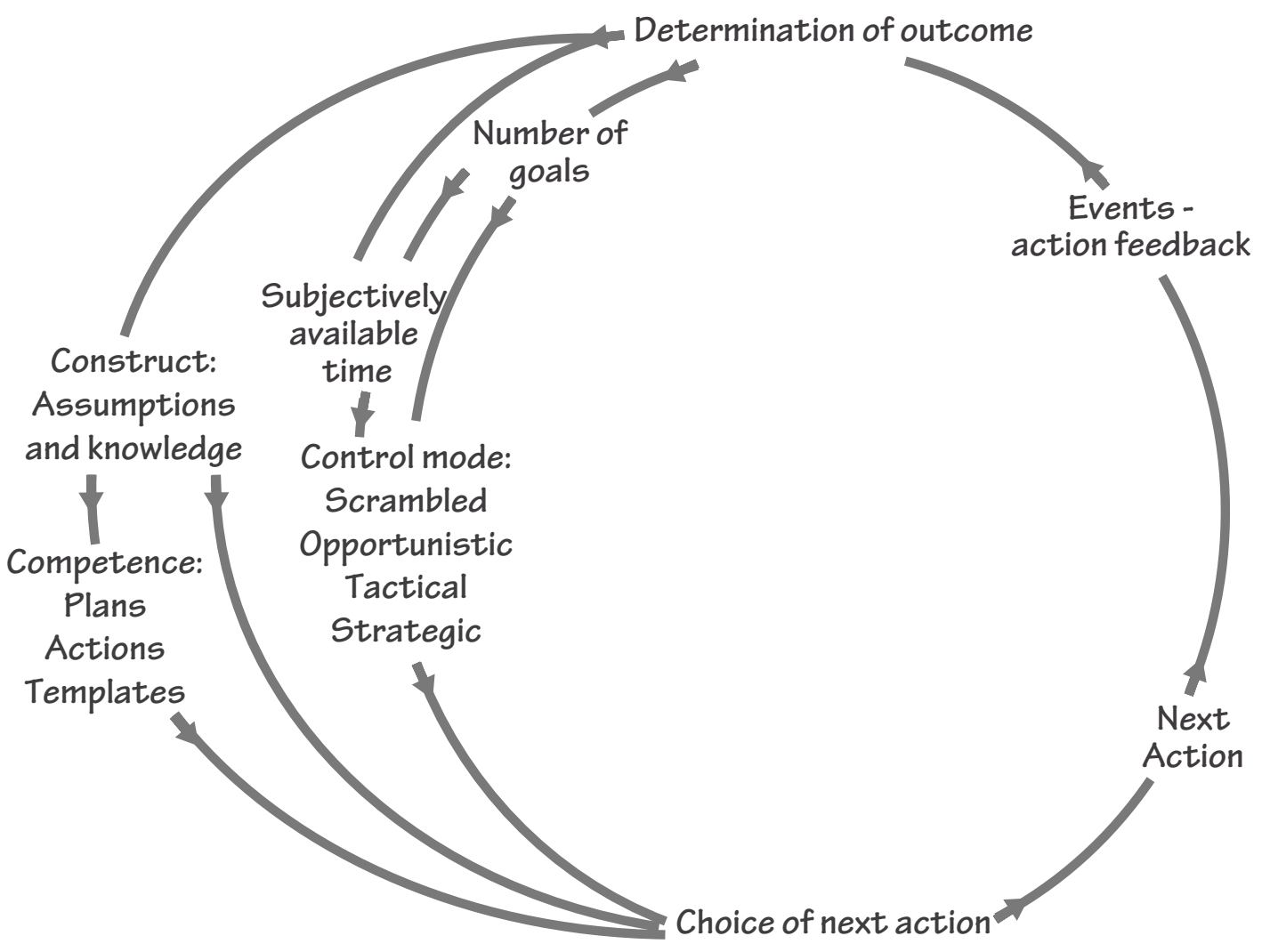

Figure 3. The contextual control model (COCOM), adapted from Hollnagel (2000). Arrows in-

dicate the direction of influence of the factors and functions in the model. 


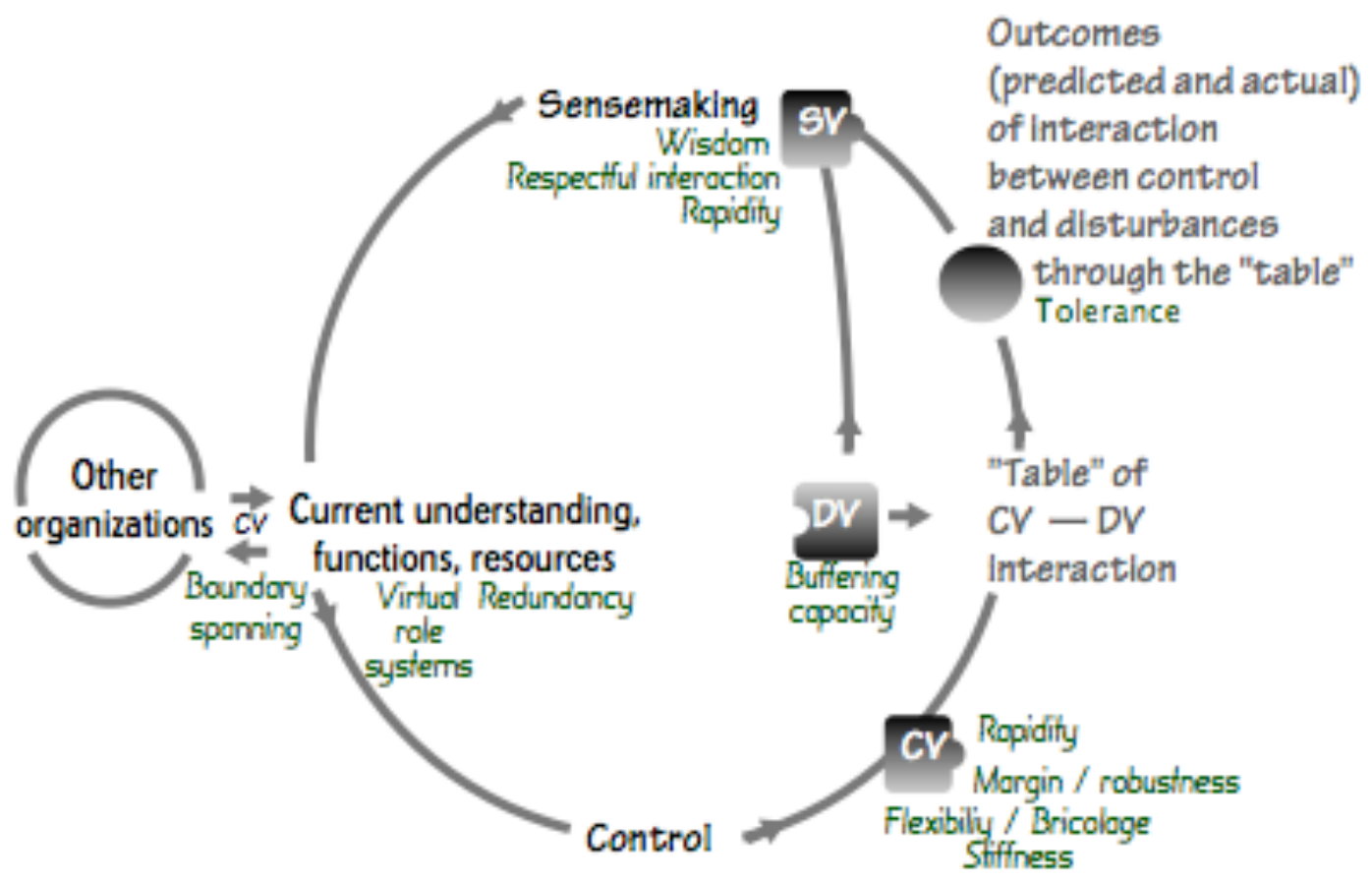

Figure 4. Basic control loop for analysis of resilience. Arrows indicate the direction of the cyclical process. 
Lundberg, J., Törnqvist, E. and Nadjm-Tehrani, S. (2012) Resilience in Sensemaking and Control of Emergency Response International Journal of Emergency Management, vol 8 no 2, p 99 - 122. DOI: 10.1504/IJEM.2012.046009

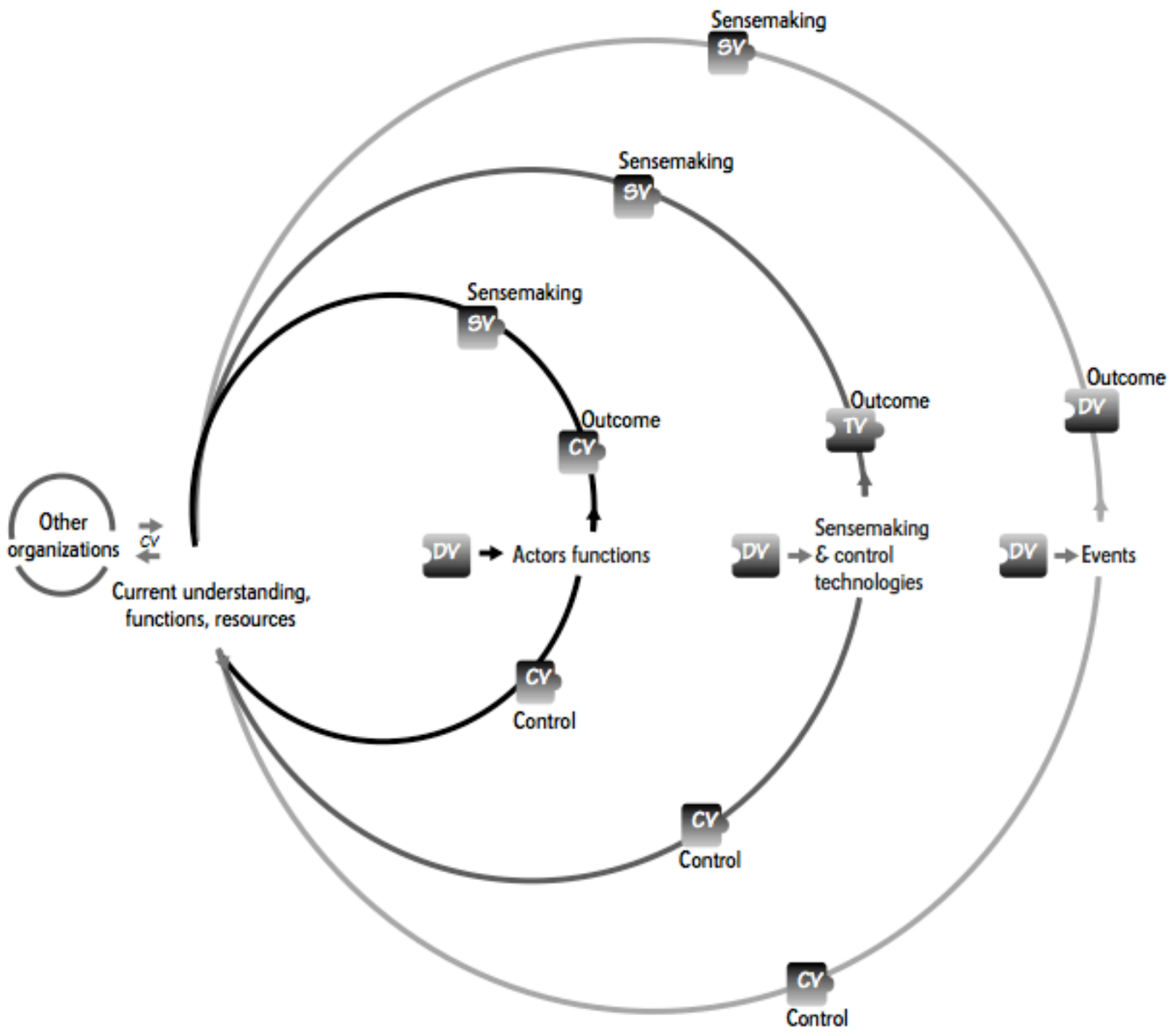

Figure 5. RESCOM - Resilient Sensemaking and Variety Control Model. Details of each loop are presented in Figure 4. Arrows indicate the direction of the cyclical process. (TV, DV, CV as outcomes illustrate that outcomes in different processes can affect each other, e.g. new or still uncontrolled disturbances or effects on technology variety or control variety) 
Lundberg, J., Törnqvist, E. and Nadjm-Tehrani, S. (2012) Resilience in Sensemaking and Control of Emergency Response International Journal of Emergency Management, vol 8 no 2, p 99 - 122. DOI: 10.1504/IJEM.2012.046009

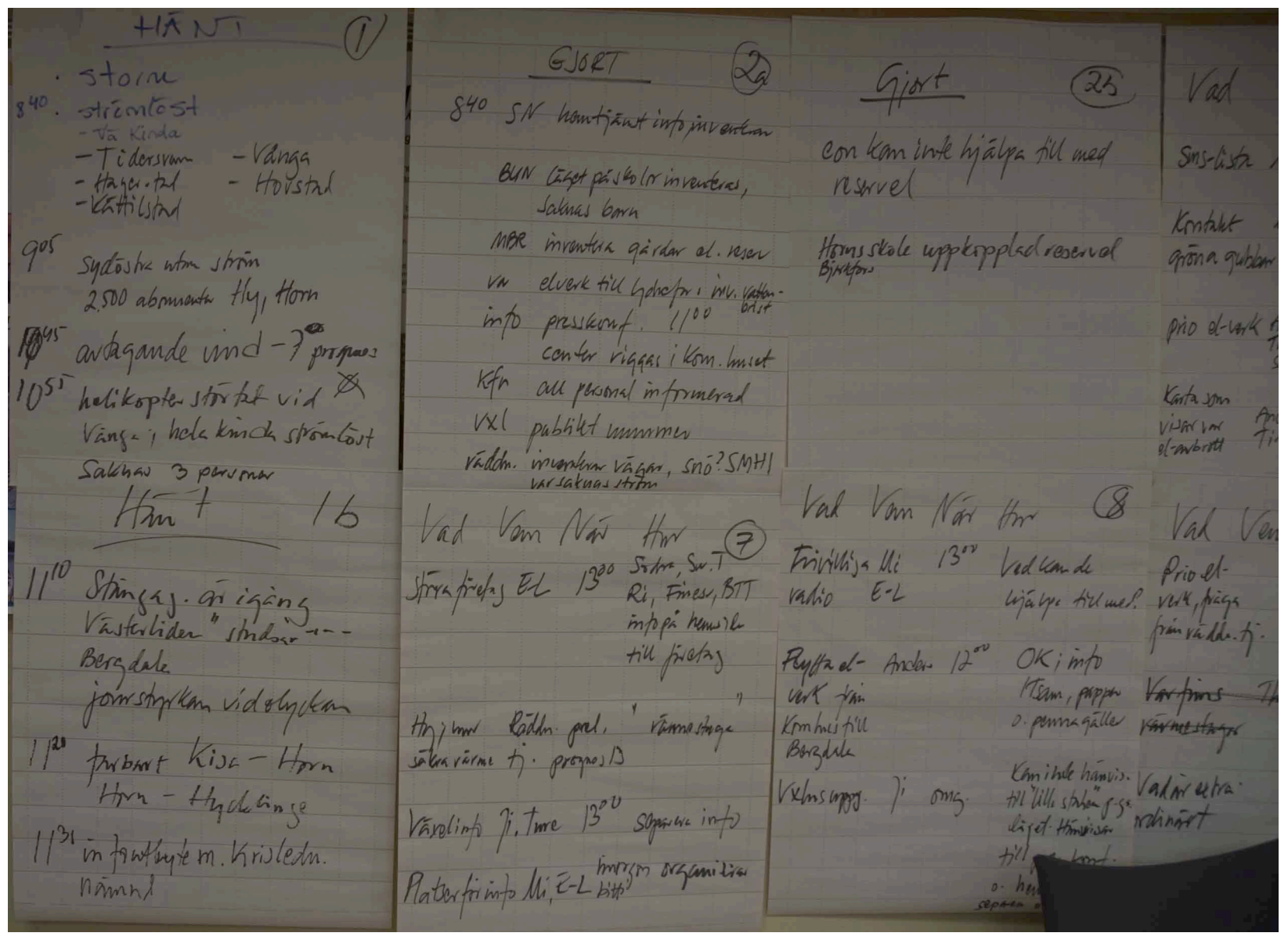

Figure 6. Notes were taken in front of the staff, but when the paper was full, it was placed on the wall on the side of the room.

Pre-print version. Published version available at: http://www.inderscience.com/search/index.php?action=record\&rec_id=46009\&prevQuery=\&ps=10\&m=or 